Original Research Paper

\title{
Mercury Contamination within Protected Areas in the Brazilian Northern Amazon-Amapá State
}

\author{
${ }^{1}$ Rossana Venturieri, ${ }^{2}$ Marcelo Oliveira-da-Costa, ${ }^{3}$ Cecile Gama and ${ }^{4}$ Christoph Bernhard Jaster \\ ${ }^{1}$ Biosciences Institute, University of São Paulo, Rua do Matão, Travessa 14, 321, 05508-900, São Paulo, Brazil \\ ${ }^{2}$ WWF-Brazil-SGCV Lote 15 s/n s. 421, Guará- Brasília, Brasil \\ ${ }^{3}$ Institute of Scientific Research and Technology of the State of Amapá - Av. Feliciano Coelho, 1509. Trem, Amapá, Brasil \\ ${ }^{4}$ Chico Mendes Institute for Biodiversity Conservation, Rua Leopoldo Machado, 1126, Amapá, Brasil
}

Article history

Received: 17-06-2016

Revised: 23-10-2016

Accepted: 16-01-2017

Corresponding Author: Marcelo Oliveira-da-Costa WWF-Brazil-SGCV Lote 15 s/n s. 421, Guará- Brasília, Brasil

Tell: (+55) 61-3364.7454

Email: marcelo@wwf.org.br

\begin{abstract}
Mercury contamination is a long-standing environmental and social problem, notably in the Amazon. The widespread use of mercury in artisanal and small-scale gold mining has driven contamination of the environment and the people, threatening biodiversity, human health and livelihoods of traditional populations. Along the border area between Brazil and French Guiana, illegal gold mining is considered a critical threat to biodiversity, a social and economic problem and a political and diplomatic issue. On the Brazilian side in Amapá state, stands the world's largest tropical forest National Park-Tumucumaque National Park (TNP). Despite its critical importance for the maintenance of ecosystem services, little is known about anthropic impacts in the area, including mercury contamination. The present study aims to assess the current levels of mercury contamination of carnivorous fish species in the TNP region as the starting point for the assessment of its impact over the integrity of protected areas and local communities. Fish samples were collected at 33 sampling sites within TNP and its surroundings. Samples of 187 most consumed local fish belonging to eight carnivore species were analyzed. Mercury was detected in $81 \%$ of the collected fish, the majority of them with individual levels above the WHO health safety limit $\left(0.5 \mu \mathrm{g} . \mathrm{g}^{-1}\right)$. Furthermore, samples from all rivers assessed presented some level of contamination. The contamination of important locally consumed fish is widespread in the study area. Important river basins in the Northern Amazon area are affected and even protected areas might be impacted by mercury. Our results suggest mercury as a significant threat to biodiversity and human health in the region. Additional studies should be conducted towards identifying the extent of the problem in the region and mitigation strategies addressing the effects of contamination must be incorporated in decision makers' priority agenda.
\end{abstract}

Keywords: Mercury Contamination, Artisanal Gold Mining, Protected Areas, Amazon

\section{Introduction}

Mercury contamination is a long-standing environmental and social problem throughout the world, especially in the Amazon (Martín-Doimeadios et al., 2014; Berzas Nevado et al., 2010). The widespread use of mercury $(\mathrm{Hg})$ in artisanal and small-scale gold mining has driven contamination of the environment and people, threatening biodiversity, human health and livelihoods of traditional population.
Artisanal gold mining accounts for nearly $12 \%$ of all the gold produced in the world and is responsible for the release of up to 1600 tons of metallic mercury every year (Veiga et al., 2014). The use of $\mathrm{Hg}$ in the extraction process is necessary for gold amalgamation. Mercury is a highly toxic metal, long lasting in the environment and has potential to reach areas far from its original source through the atmosphere.

The importance of mercury contamination through fish intake in humans is already well established. 
Through bioaccumulation and bio magnification processes, fish retain mercury in their muscles and organs, especially Methylmercury, which is transferred to people eating contaminated fish. In regions where there is a high consumption of fish such as in the Amazon, the potential for human contamination by mercury through diet is substantial. Carnivorous fish are used as indirect indicators of mercury contamination. Mercury contamination can be acute or chronic and the intoxication produces effects that range from mild to lethal, with alterations on the central nervous system (Berzas Nevado et al., 2010; Counter and Buchanan, 2004) and genotoxicity (Crespo-López et al., 2011; WHO 2013; 2007).

Although it is a well-established research topic in the Brazilian Amazon, studies on $\mathrm{Hg}$ contamination are geographically and temporally limited. Nevertheless, these studies suggest large-scale environmental disruption, with widespread contamination, affecting biodiversity (Santos et al., 2015; Kehrig et al., 2008; Dolbec et al., 2001; Bidone et al., 1997; Porvari, 1995) and impacting health of local communities that relies on fish as a protein source (Martín-Doimeadios et al., 2014; De Oliveira Santos et al., 2000), including indigenous people (Barbosa et al., 1998; Basta et al., 2016).

Whilst the gold rush documented in the 80 's has decreased in many areas in the Brazilian Amazon, throughout the last two decades artisanal small-scale gold mining has dramatically increased in the Northern Amazon. Especially in the Brazilian border with French Guiana and Suriname, known as Guiana Shield Eco-region (GSE). GSE covers 250 million hectares and contains one of the largest complexes of uninterrupted primary tropical forest on Earth, endowed with a unique biodiversity and crucial freshwater resources. Despite its critical importance for climate stability and protection of natural, social and cultural capital, deforestation and forest degradation are of increasing concern in the GSE. Deforestation due to gold mining activities is of particular concern and it has grown in Guiana, French Guiana and Suriname (Alvarez-Berríos and Aide, 2014; Legg et al., 2015; Rahm et al., 2015). Artisanal gold mining activities have slightly decreased in Brazil in recent years, but there are still several gold mining sites (garimpos) in use, many of them illegally installed within Protected Areas.

In the state of Amapá, border with the French Guiana, stands the world's largest tropical forest National Park-Tumucumaque National Park. Created in 2002, this national park legally protects 3.867 .000 hectares and despite its critical importance, there is a scarce understanding about its biodiversity. The area of TNP has been historically affected by artisanal gold mining, even after the creation of the protected area. Although environmental mercury contamination in the area represents a strong threat to fauna and local communities, it is still poorly understood.

The present study aims to assess the current levels of $\mathrm{Hg}$ contamination of carnivorous fish species in the TNP region as the starting point for the assessment of its impact on the integrity of protected areas and local communities. The results will contribute to the improvement of the TNP management and protection as it will provide information to support public policies at federal and state level.

\section{Materials and Methods}

\section{Study Area}

This study was conducted in the area of the TNP

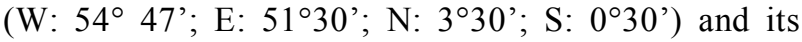
area of influence (buffer zone). This national park protects nearly $64,000 \mathrm{~km}$ of rivers where samples were collected in 33 sites.

The potential influence of gold mining areas as pollution sources of mercury contamination in fish was the criteria used to define the sampling sites (Fig. 1). Except for the sampling sites in the Tajauí Riverdownstream from a legalized gold mining site"Garimpo do Lourenço"-, the exact location of most gold mining sites in the region are unmapped. These illegal gold mining sites are located deep in the forest and protected by criminal networks that prevent their discovery. For this reason, as references we used information from the TNP management plan, gold mining deforestation maps (Rahm et al., 2015), literature (Tritsch et al., 2015) and information obtained in interviews with protected area managers and locals with knowledge of gold mining history in the region.

In addition, as an indicator of the existence of a potential mining site, we analyzed differences in the color of river water. In the region, gold is extracted from alluvial deposits on riverbanks and streams, which are bombarded with pressurized water jets leaving the color of the river water muddy due to suspended material and deeper soils reached. This muddy water travels long distances and can often indicate the existence of mining activity in the region.

In this study, the main tributaries that surround or receive discharges from rivers that originate inside the TNP were considered and samples were collected at points downstream from the potential mines (Table 1). Samples were also collected in places with little or no influence of mining, to be used as a control sample. 


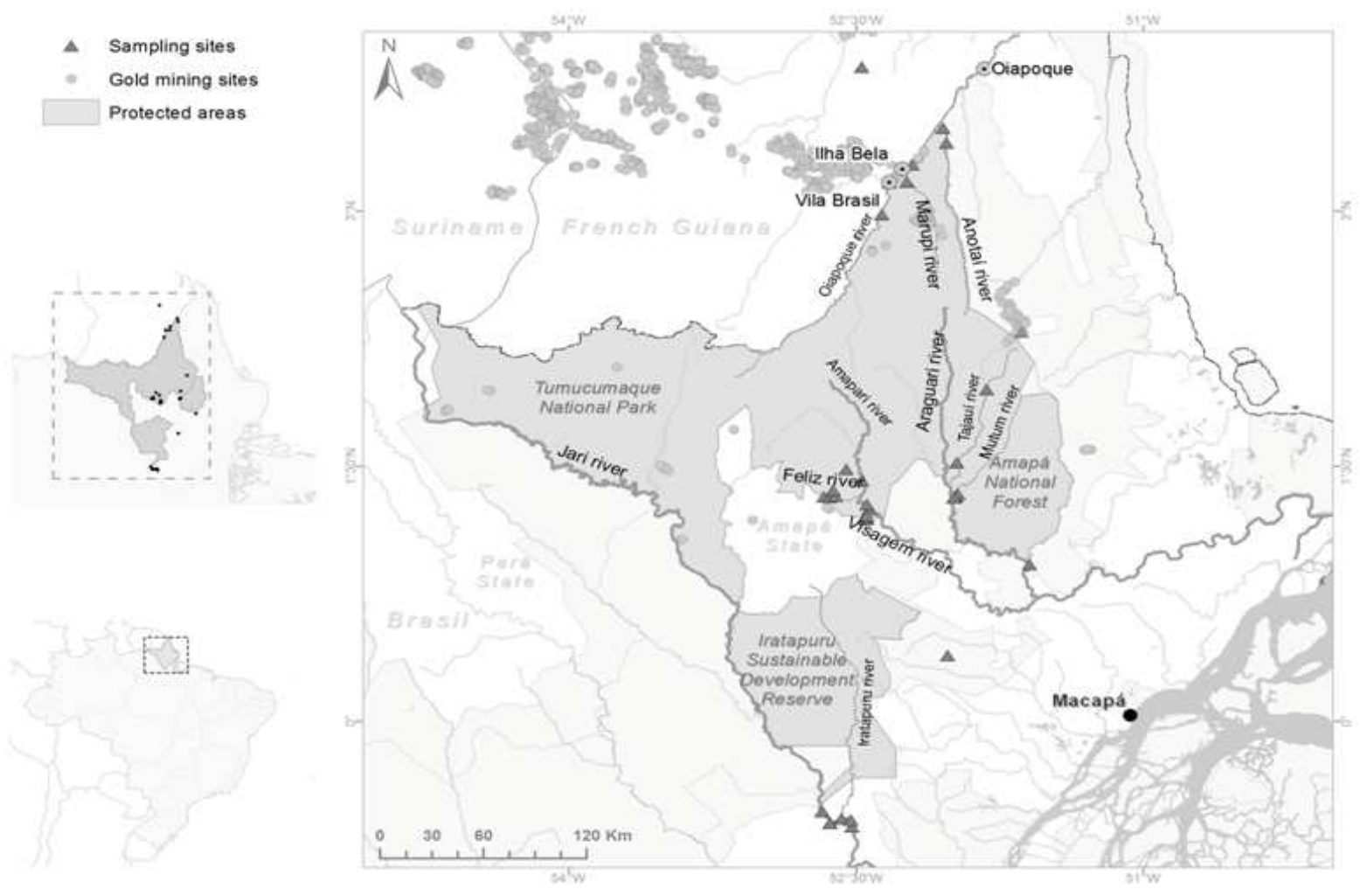

Fig. 1. Study area showing sampling sites

\section{Sample Collection and Preparation}

Muscle tissue samples of 187 animals from eight different fish species were collected during three field trips between July and September 2015. Our study focused on catching carnivorous fish species, as they would have the highest probability of accumulating mercury from other fish that are eaten as food sources (Legg et al., 2015; WHO, 1990). Thus, samples were collected from carnivorous fish species widely consumed by local people: Piranha preta (Serrasalmus rhombeus), trairão (Hoplias aimara), pirapucu (Boulengerella cuvieri), piranha amarela (Serrasalmus maculatus), mandubé (Ageneiosus inermis), cachorra (Hydrolicus armatus), pintado (Pseudoplatystoma fasciatum) and pirarara (Phractocephalus hemioliopterus).

Fish were caught by local fishermen hired for the research project. Gillnets, hooks and hand lines, fishing rod and long line were used. According to the fishermen, each fish species is effectively captured with particular gear. Therefore, $H$. aimara specimens were mainly caught with fishing rod, hook and line; $S$. rhombeus, $S$. maculatus and $H$. armatus were captured with fishing rod, hook and line; B. cuvieri with gillnet and $P$. fasciatum and $P$. hemioliopterus with long line. At each collection point a sample standard was established with the target capture of five individuals for each species, which were processed as they were caught, without consideration of size, weight, etc. The surplus fish caught were returned to the river. In some cases, it was not possible to capture five samples of each species due to time constraints at each sample site.

Each specimen was identified at the species level by a specialist; weighed; measured; and placed in a tray lined with a disposable plastic sheet to prevent contamination. Skin and scales were removed with the aid of tweezers and disposable scalpels and a muscle sample of 60 to $100 \mathrm{~g}$ was extracted from each specimen. The samples were placed in glass vials; sealed and secured with plastic; labeled; and packed in coolers with ice until they arrived at the laboratory.

\section{Mercury Analysis}

Total mercury analysis was carried out in the Anatech/Eurofins Laboratory (São Paulo, Brazil) using Cold Vapor Atomic Fluorescence Spectrometry (EPA, 2002), as briefly described: (1) A 100 to $2000 \mathrm{~mL}$ sample is collected directly into a cleaned, pretested, fluoropolymer or glass bottle using sample handling techniques designed for collection of mercury at trace levels. (2) For dissolved $\mathrm{Hg}$, the sample is filtered through a $0.45 \mu \mathrm{m}$ capsule filter prior to preservation. (3) The sample is preserved by adding either pretested $12 \mathrm{~N}$ hydrochloric acid $(\mathrm{HCl})$ or bromine monochloride $(\mathrm{BrCl})$ 
solution. (4) Prior to analysis, all $\mathrm{Hg}$ in a $100 \mathrm{~mL}$ sample aliquot is oxidized to $\mathrm{Hg}(\mathrm{II})$ with $\mathrm{BrCl}$. (5) After oxidation, the sample is sequentially reduced with $\mathrm{NH}_{2} \mathrm{OH} @ \mathrm{HCl}$ to destroy the free halogens, then reduced with stannous chloride $\left(\mathrm{SnCl}_{2}\right)$ to convert $\mathrm{Hg}$ (II) to volatile $\mathrm{Hg}(0)$. (6) The $\mathrm{Hg}(0)$ is separated from solution either by purging with nitrogen, helium, or argon, or by vapor/liquid separation. $\operatorname{The} \operatorname{Hg}(0)$ is collected onto a gold trap. (7) The $\mathrm{Hg}$ is thermally desorbed from the gold trap into an inert gas stream that carries the released $\mathrm{Hg}(0)$ to a second gold (analytical) trap. The $\mathrm{Hg}$ is desorbed from the analytical trap into a gas stream that carries the $\mathrm{Hg}$ into the cell of a cold-vapor atomic fluorescence spectrometer (CVAFS) for detection. (8) Quality is assured through calibration and testing of the oxidation, purging and detection systems.

\section{Statistical Analyses}

The data was expressed as the mean $\pm \mathrm{SD}$. They were submitted to variance analysis using Generalized Linear Model-GLM ANOVA- (Myers et al., 2010) to compare the results among rivers. When significant differences were observed, the means were compared using LSD univariate test with $\alpha=0.01$. Illustrative graphs were built using Statistica software 6.0 (Statsoft, Tulsa, United States of America). Species that were under a sampling threshold of three individuals were not considered for the analyses and neither were samples where the probability of belonging to the species group was less than 0.001 (considered as floating point: Sokal and Rohlf, 1995). $\mathrm{Hg}$ values $<0.1$ were considered as 0.1 for analyses, with no results alterations.

Table 1. Correlation between sampling sites within TNP and potential influence of gold mining

\begin{tabular}{|c|c|c|c|c|}
\hline Main river & Tributaries-sampling sites & $\begin{array}{l}\text { Coordinates of sampling } \\
\text { sites (central) }\end{array}$ & $\begin{array}{l}\text { Characteristics of sample } \\
\text { sites within TNP }\end{array}$ & $\begin{array}{l}\text { Probable correlation to gold } \\
\text { mining activity }\end{array}$ \\
\hline \multirow[t]{2}{*}{ Amapari River } & Amapari River & $\begin{array}{l}01^{\circ} 16^{\prime} 54.00^{\prime \prime} \mathrm{N} \\
052^{\circ} 23^{\prime} 31.98^{\prime \prime} \mathrm{W}\end{array}$ & TNP Southern boundary & $\begin{array}{l}\text { Low influence of new gold } \\
\text { mining sites in the sampling } \\
\text { areas (according to reports of } \\
\text { local residents and TNP } \\
\text { managers) }\end{array}$ \\
\hline & Feliz River & $\begin{array}{l}01^{\circ} 11^{\prime} 34.54^{\prime \prime} \mathrm{N} \\
052^{\circ} 26^{\prime} 40.52^{\prime \prime} \mathrm{W}\end{array}$ & $\begin{array}{l}\text { TNP boundary with } \\
\text { Waiãpi indigenous land }\end{array}$ & $\begin{array}{l}\text { Low influence of recent gold } \\
\text { mining activities (report of } \\
\text { mining activity between } 1980 \\
\text { and 1992) }\end{array}$ \\
\hline \multirow[t]{2}{*}{ Araguari River } & $\begin{array}{l}\text { Tajaui River (50 km } \\
\text { from Garimpo Lourenço) } \\
\text { Tajaui River (100 km } \\
\text { from Garimpo Lourenço) } \\
\text { Tajaui River } \\
\text { (river mouth) }\end{array}$ & $\begin{array}{l}01^{\circ} 57^{\prime} 12.99^{\prime \prime} \mathrm{N} \\
051^{\circ} 49^{\prime} 15.99^{\prime \prime} \mathrm{W} \\
01^{\circ} 31^{\prime} 28.99^{\prime \prime} \mathrm{N} \\
051^{\circ} 58^{\prime} 27.99^{\prime \prime} \mathrm{W} \\
00^{\circ} 23^{\prime} 26.99^{\prime \prime} \mathrm{N} \\
052^{\circ} 01^{\prime} 26.00^{\prime \prime} \mathrm{W}\end{array}$ & $\begin{array}{l}\text { Boundary of TNP in the } \\
\text { South-Central region. } \\
\text { The headspring is inside } \\
\text { TNP and empties into the } \\
\text { Araguari River }\end{array}$ & $\begin{array}{l}\text { High influence of "Garimpo do } \\
\text { Lourenço", where gold mining } \\
\text { waste is dumped directly into } \\
\text { small streams flowing into the } \\
\text { Tajaui River. }\end{array}$ \\
\hline & Mutum River & $\begin{array}{l}01^{\circ} 19^{\prime} 04.00^{\prime \prime} \mathrm{N} \\
051^{\circ} 59^{\prime} 21.00^{\prime \prime} \mathrm{W}\end{array}$ & $\begin{array}{l}\text { Boundary between TNP } \\
\text { and Amapá National Forest }\end{array}$ & $\begin{array}{l}\text { Low gold mining influence at } \\
\text { the location sampled; no direct } \\
\text { connection to the "Garimpo do } \\
\text { Lourenço" }\end{array}$ \\
\hline \multirow[t]{4}{*}{ Oiapoque River } & Vila Brasil & $\begin{array}{l}03^{\circ} 10^{\prime} 12.90^{\prime \prime} \mathrm{N} \\
052^{\circ} 19^{\prime} 48.50^{\prime \prime} \mathrm{W}\end{array}$ & $\begin{array}{l}\text { Settlement within the TNP- } \\
\text { located opposite the mouth } \\
\text { of the Camopi River (French } \\
\text { Guiana), which flows into } \\
\text { the Oiapoque River. }\end{array}$ & $\begin{array}{l}\text { Influence of the various gold } \\
\text { mining sites located along } \\
\text { Camopi River }\end{array}$ \\
\hline & Igarapé '2 bocas' & $\begin{array}{l}03^{\circ} 16^{\prime} 30.35^{\prime \prime} \mathrm{N} \\
052^{\circ} 12^{\prime} 40.40^{\prime \prime} \mathrm{O}\end{array}$ & $\begin{array}{l}\text { Approximately } 23 \mathrm{~km} \\
\text { downstream from Vila Brazil, } \\
6 \mathrm{~km} \text { downstream of Marupi } \\
\text { River and } 30 \mathrm{~km} \text { upstream } \\
\text { from the mouth of Anotai river }\end{array}$ & $\begin{array}{l}\text { Possible influence of large } \\
\text { numbers of gold mining sites } \\
\text { located } 35 \mathrm{~km} \text { on the Sikini } \\
\text { River (French Guiana), } \\
\text { according to data from } \\
\text { Rahm et al. }(2015)\end{array}$ \\
\hline & Marupi River & $\begin{array}{l}03^{\circ} 10^{\prime} 58.00^{\prime \prime} \mathrm{N} \\
052^{\circ} 14^{\prime} 09.99^{\prime \prime} \mathrm{W}\end{array}$ & $\begin{array}{l}\text { Downstream from Vila Brazil- } \\
\text { a settlement within TNP }\end{array}$ & $\begin{array}{l}\text { Influence of illegal garimpos } \\
\text { located } 25 \mathrm{~km} \text { from the sample } \\
\text { site, according to data from } \\
\text { Rahm et al. (2015). }\end{array}$ \\
\hline & Anotai River & $\begin{array}{l}03^{\circ} 29^{\prime} 25.00^{\prime \prime} \mathrm{N} \\
052^{\circ} 02^{\prime} 53.99^{\prime \prime} \mathrm{W}\end{array}$ & $\begin{array}{l}\text { Eastern boundary of TNP, } \\
\text { tributary of the Oiapoque River. }\end{array}$ & $\begin{array}{l}\text { Influence of illegal gold mining } \\
\text { possibly located within the Park }\end{array}$ \\
\hline Jari River & Jari River & $\begin{array}{l}00^{\circ} 35^{\prime} 43.00^{\prime \prime} \mathrm{S} \\
052^{\circ} 38^{\prime} 09.98^{\prime \prime} \mathrm{W}\end{array}$ & $\begin{array}{l}\text { Distant } 150 \mathrm{~km} \text { from the TNP, } \\
\text { at the boundary of the } \\
\text { sustainable development reserve } \\
\text { of Iratapuru River }\end{array}$ & $\begin{array}{l}\text { Strong influence of illegal } \\
\text { mining upstream of the sampling } \\
\text { site next to TNP. Old illegal gold } \\
\text { mining areas still active, with } \\
\text { possible impact on neighboring } \\
\text { protected areas. }\end{array}$ \\
\hline
\end{tabular}




\section{Results}

\section{Mercury Levels in Fish}

In this study of the187 fish samples collected, $81 \%$ had detectable mercury levels. Individuals from 5 out of 8 species sampled exceeded the mercury guideline for human consumption set by the World Health Organization $\left(0.5 \mu \mathrm{g} . \mathrm{g}^{-1}\right)$ B. cuvieri $(73 \%), H$. armatus $(60 \%), H$. aimara $(58 \%)$, A. inermis $(56 \%)$ and $S$. rhombeus $(53 \%)$. Fish that showed higher individual $\mathrm{Hg}$ values were $H$. armatus $\left(2.64 \mu \mathrm{g} . \mathrm{g}^{-1}\right), H$. aimara $(1.90$ $\left.\mu \mathrm{g} . \mathrm{g}^{-1}\right)$ and $S$. rhombeus $\left(1.62 \mu \mathrm{g} . \mathrm{g}^{-1}\right)$. S. maculatus was the species with the lowest mercury average value $\left(0.12 \pm 0.08 \mu \mathrm{g} \cdot \mathrm{g}^{-1}\right)$ (Table 2).

\section{Mercury Contamination in the Main Rivers and Sampling Sites}

Among the main rivers, the Oiapoque had the lowest average $\mathrm{Hg}$ concentration $\left(0.17 \mu \mathrm{g} \cdot \mathrm{g}^{-1}\right)$ and was statistically different from the others. The Amapari $\left(0.36 \mu \mathrm{g} . \mathrm{g}^{-1}\right)$ and Jari rivers $\left(0.50 \mu \mathrm{g} . \mathrm{g}^{-1}\right)$ did not differ statistically from each other. The Araguari River showed the highest average concentration $\left(0.80 \mu \mathrm{g} . \mathrm{g}^{-1}\right)$ above the reference value set by WHO, being statistically different from the others.

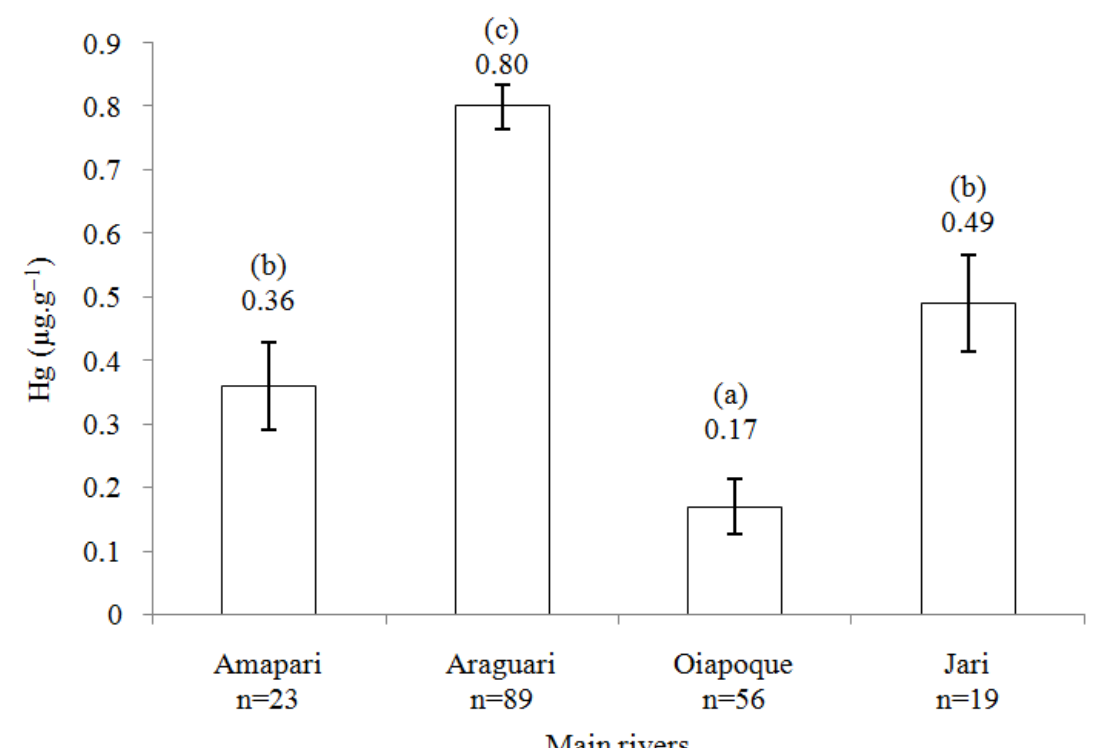

(A)

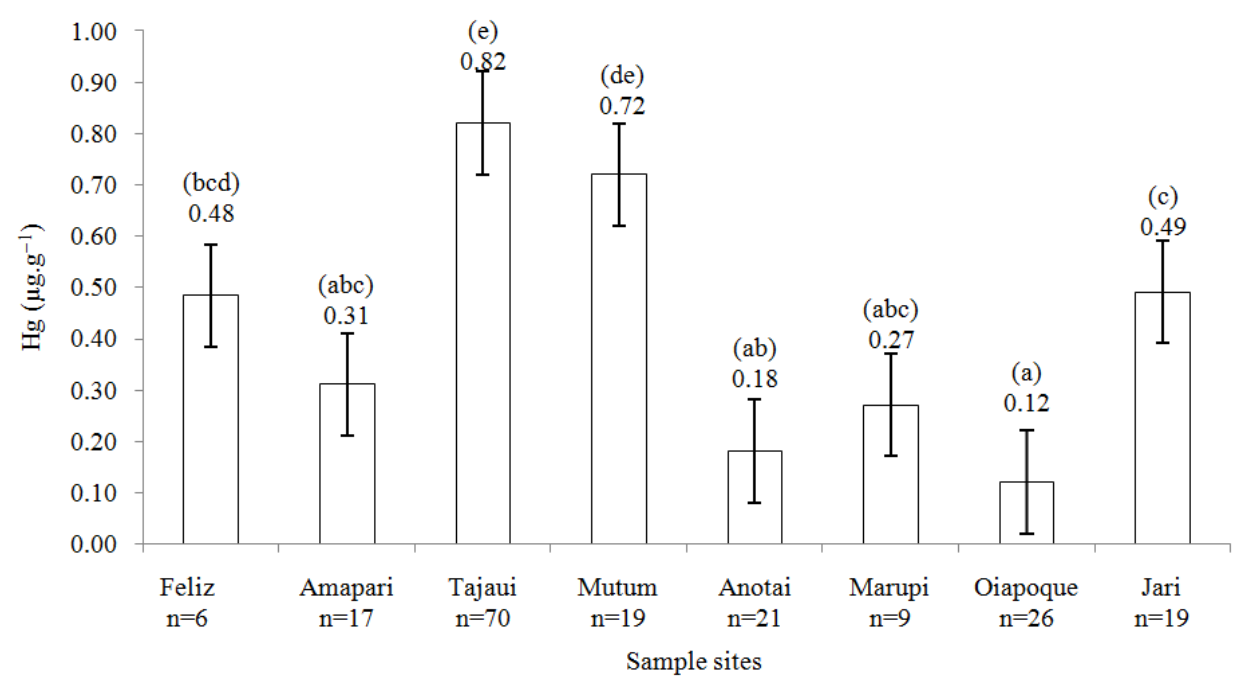

(B)

Fig. 2. Means + SD of total $\mathrm{Hg}\left(\mu \mathrm{g} \cdot \mathrm{g}^{-1}\right)$ in fish from the main rivers (A) and sample sites (B). Vertical bars denote confidence interval of 0.95 . Same letters denote no statistically significant differences among main rivers and among sample sites (ANOVA) 
Table 2. Mercury ( $\mathrm{Hg})$ concentration found for each fish species

\begin{tabular}{|c|c|c|c|c|c|c|c|c|}
\hline Species & $\begin{array}{l}\text { Mean } \\
\text { weight (g) }\end{array}$ & $\begin{array}{l}\text { Mean } \\
\text { length }(\mathrm{cm})\end{array}$ & $\begin{array}{l}\text { Percentage of } \\
\text { individuals with } \\
\text { detectable } \mathrm{Hg} \\
\text { levels }(\%)\end{array}$ & $\begin{array}{l}\text { Values* } \\
\text { Above } \\
\text { reference } \\
(\%)\end{array}$ & $\begin{array}{l}\text { Mean } \mathrm{Hg} \\
\text { concentration } \\
\left(\mu \mathrm{g} \cdot \mathrm{g}^{-1}\right)\end{array}$ & $\begin{array}{l}\text { Standard } \\
\text { Deviation } \\
\left(\mu \mathrm{g} \cdot \mathrm{g}^{-1}\right)\end{array}$ & $\begin{array}{l}\mathrm{Hg} \\
\text { concentration } \\
\text { range } \\
\left(\mu \mathrm{g} \cdot \mathrm{g}^{-1}\right)\end{array}$ & $\mathrm{n}$ \\
\hline H. aymara & 3.31 & 61 & 89 & 58 & 0.60 & 0.05 & $<0.10-1.90$ & 61 \\
\hline S. rhombeus & 847 & 31 & 83 & 53 & 0.50 & 0.06 & $<0.10-1.62$ & 46 \\
\hline B. cuvieri & 1.81 & 61 & 88 & 73 & 0.63 & 0.09 & $<0.10-1.37$ & 17 \\
\hline A. inermis & 752 & 42 & 96 & 56 & 0.65 & 0.07 & $<0.10-1.37$ & 26 \\
\hline S. maculatus & 226 & 21 & 35 & 0 & 0.12 & 0.08 & $<0.10-0.23$ & 25 \\
\hline H. armatus & 2.41 & 54 & 100 & 60 & 1.17 & 0.17 & $0.24-2.64$ & 5 \\
\hline P. fasciatum & 1.64 & 51 & 100 & 0 & 0.28 & 0.22 & $0.18-0.41$ & 3 \\
\hline P. hemioliopterus & 4.51 & 59 & 100 & 25 & 0.33 & 0.19 & $0.14-0.60$ & 4 \\
\hline
\end{tabular}

*0.5 Hg( $\left.\mu \mathrm{g} \cdot \mathrm{g}^{-1}\right)$

The rivers/sample sites with average levels of $\mathrm{Hg}$ in fish above the reference value were Tajauí and Mutum, with $0.82 \pm 0.03$ and $0.72 \pm 0.07 \mu \mathrm{g} . \mathrm{g}^{-1}$, respectively.

Statistically significant differences were found only between Tajaui and Mutum rivers compared to the other rivers and there was no difference between them (Fig. 2).

\section{Discussion}

The results showed that 151 samples of fish specimens analyzed had mercury levels in muscle tissues. Five of the eight species studied had more than half of the individuals analyzed exceeding the WHO health safe limit for mercury.

H. aimara had mercury levels detected in $89 \%$ of the samples, with an average of $0.60 \pm 0.04 \mu \mathrm{g} . \mathrm{g}^{-1}$ and $58 \%$ of the samples exceeded the WHO limit. This average was slightly higher than the values reported by Lima et al. (2015) for the Cassipore River, also in the Amapá state $\left(0.535 \pm 0.03 \mu \mathrm{g} . \mathrm{g}^{-1}\right)$ and by Legg et al. (2015) in French Guiana $\left(0.61 \pm 0.22 \mu \mathrm{g}^{-\mathrm{g}^{-1}}\right)$.

As for species-level concentration of $\mathrm{Hg}$, it was extremely high for $H$. aimara, above $1.5 \mu \mathrm{g} \cdot \mathrm{g}^{-1}$ in several specimens, one showing $1.9 \mu \mathrm{g} \cdot \mathrm{g}^{-1}$. Another individual had $11.1 \mu \mathrm{g} . \mathrm{g}^{-1}$, a very high concentration and superior to all other species analyzed in this study, which was double-checked and confirmed in the laboratory. That was the only data point discarded as an outlier, because the probability of belonging to the sample was extremely low. Although excluded from the analysis, it is noteworthy because the data may eventually appear in other studies. A similar value $\left(10.64 \mu \mathrm{g} . \mathrm{g}^{-1}\right)$ was reported by Durrieu et al. (2005) on the Courcibo River, in French Guiana, demonstrating the great potential that $S$. aimara has to accumulate mercury. This finding is of particular concern because this species is one of the most consumed by people living in the study area.

For B. cuvieri, $88 \%$ had mercury levels averaging $0.63 \pm 0.09 \mu \mathrm{g} . \mathrm{g}^{-1}$, of which $73 \%$ exceeded WHO threshold. The sample with the highest level had 1.37 $\mu \mathrm{g} . \mathrm{g}^{-1}$, more than twice the WHO reference value.
For S. rhombeus, detected mercury levels occurred in $83 \%$ of specimens collected and over half of them exceeded WHO limit. Although the average value for this species $\left(0.50 \pm 0.06 \mu \mathrm{g} . \mathrm{g}^{-1}\right)$ is within the safety limit set by WHO, several specimens showed higher levels and one of them had value of $1.6 \mu \mathrm{g} . \mathrm{g}^{-1}$, similar to values reported by Legg et al. (2015) in Brokopondo Reservoir, Suriname. In turn, S. maculatus collected in the Oiapoque region showed values $\left(0.125 \pm 0.07 \mu \mathrm{g} . \mathrm{g}^{-1}\right)$ below the safety limit, theoretically presenting no risk for human consumption.

Mercury levels were detected in $96 \%$ of all $A$. inermis individuals analyzed, with a mean value of $0.65 \pm 0.07 \mu \mathrm{g} . \mathrm{g}^{-1}$, of which $56 \%$ of the samples exceeded WHO guideline concentration. Despite being a very popular fish in the sampled areas, this species is not very recurrent in similar studies in Guianas and Suriname, except for Maury-Brachet et al. (2006), who found $2.67 \pm 0.52 \mu \mathrm{g} . \mathrm{g}^{-1}$ for Ageneiosus brevifilis in French Guiana (another species of the same genus and with the same common name in Brazil). In studies on the Madeira River, Bastos et al. (2008) found the average value of $0.851 \mu \mathrm{g} . \mathrm{g}^{-1}$ for $A$. brevifilis.

Regarding the species collected in the Jari River $(P$. fasciatum, $P$. hemioliopterus and $H$. armatus), all fish caught had detectable levels of mercury, but only H.armatus showed an average level above the WHO reference value. This species showed the highest average value and the highest individual maximum value found in this study: $1.17 \pm 0.17 \mu \mathrm{g} . \mathrm{g}^{-1}$ and 2.64 $\mu \mathrm{g} . \mathrm{g}^{-1}$, respectively. For this species, $54 \%$ of the samples had detectable mercury levels and for $60 \%$ the WHO limit was exceeded. Bastos et al. (2008) found $0.727 \mu \mathrm{g} . \mathrm{g}^{-1}$ for $P$. hemioliopterus and $0.66 \mu \mathrm{g} . \mathrm{g}^{-1}$ for $P$. fasciatum in the Madeira River. Legg et al. (2015) describe a significant correlation between mercury found in the hair and the amount of fish consumed by people surveyed in French Guiana, mostly for those people who showed preference for the most susceptible fish species to mercury contamination, including $P$. fasciatum and $H$. aimara. 
It is noteworthy that the number of $P$. fasciatum and $H$. hemioliopterus specimens collected was small, which may introduce some error in the analysis, especially regarding the low values of $\mathrm{Hg}$ found for $P$. fasciatum and $H$. hemioliopterus.

Analyzing the overall results, it appears that contamination levels found for $H$. aimara and $S$. rhombeus sampled in Amapá are similar to data reported for the Cassiporé River (Lima et al., 2015), thereby increasing the geographic scope of potentially impacted areas. The results are also consistent to those reported for the same species in Guianas and Suriname, where mercury contamination is already well established (Legg et al., 2015 for extensive review).

Therefore, it seems reasonable to assume that the contamination observed in the Guianas and Suriname also extends to Northern Brazil. Of course, this assumption requires additional studies to be confirmed. Especially considering that mercury levels suffer variations among species in relation to size, age, season, etc. Although the direct use of natural resources in national parks-strictly protected areas-is not allowed by Brazilian national regulation, the TNP is surrounded by four multiple use protected areas (Amapá National Forest, Amapá State Forest, Waiãpi Indigenous land and Iratapuru Sustainable Development Reserve), where traditional communities (riverine and indigenous tribes) rely heavily on fish as the main source of dietary protein. This is a concern, since some of the contaminated fish (A. inermis, $H$. aimara and B. cuvieri) are the most consumed and commercialized fish species in the area (Soares et al., 2012).

Although the parameters usually considered as "safe" were used as reference values, one cannot say that there are safe limits for consumption of fish contaminated with mercury. These limits have been constantly revised and reduced (USEPA, 2002; Evers et al., 2014) and may also be questioned as a parameter for populations that consume fish intensively (ZMWG, 2009; Evers et al., 2014; USEPA, 2002), as it happens to many communities in the Amazon. For example, the criteria used by USEPA (2002), of $0.3 \mu \mathrm{g} . \mathrm{g}^{-1}$ of methyl mercury, refers to a concentration in fish tissue based on a consumption rate of $17.5 \mathrm{~g}$ of fish/day, which is smaller than those typically practiced by the riverine populations in the study area.

According to ZMWG (2009), levels below 0.5 $\mu \mathrm{g} . \mathrm{g}^{-1}$ of $\mathrm{Hg}$ in fish are not safe for people who have a diet rich in fish. This statement is confirmed by a recent study by Basta et al. (2016), where they found high levels of mercury contamination in Yanomami indigenous in Xingu, although the fish tissue samples they ate had low levels of $\mathrm{Hg}$.

Therefore, despite the unavailability of data on mercury contamination in people for this work, our data suggests that human $\mathrm{Hg}$ contamination in the study area is highly likely. This is corroborated by the discovery of ovarian failure caused by mercury contamination in the director of the Biological Reserve of Piratuba, in Amapá (Pinha, personal communication, March 6, 2016).

It is clear that people living in this region are exposed to dangerous levels of mercury. Thus, it should be considered not only a threat to human health, especially traditional communities and settlements located downstream of gold mining sites, but also to wildlife dependent on aquatic resources (Malm et al., 1990).

Fish-eating animals accumulate mercury at concentrations known to impair animal behavior (Basu et al., 2005), especially top-level predators (Aula et al., 1994). Although incidents of $\mathrm{Hg}$ poisoning in wild mammals are rare, perhaps as a result of practitioners inability to observe and demonstrate the impacts, rather than an absence of the disease (Wren, 1986), mercury is known to be partially responsible for the decline of North American otters (Lutra canadensis) and European otters (Lutra lutra) (Gutleb et al., 1998; Wren, 1985). The giant otter (Pteronura brasiliensis) is registered in the TNP area. It is classified as endangered species (IUCN, 2015) and its diet resembles that of the Lutra lutra. Gutleb et al. (1997) and Uryu et al. (2001) using the tolerated $\mathrm{Hg}$ concentration set by Kruuk and Conroy (1991) for the European otter $\left.(0.1 \mu \mathrm{g} \mathrm{kg})^{-1}\right)$ concluded that the giant otter was in danger in Manu National park and in the Tapajós basin. Therefore, we conclude that the giant otter in this study area are also threatened by mercury contamination.

Although $\mathrm{Hg}$ contamination was found in $81 \%$ of the samples, some limitations of the study should be considered. One of them is related to the difficulty of correlating the levels of contamination with the proximity of the contaminant source. Gold mining areas are mostly illegal in the region and are located in hidden areas of difficult access. However, the extent of contamination correlates well with reported mining areas, notably in the Tajaui River, influenced by the well-known gold mining site 'Garimpo do Lourenço'.

Fish from Tajaui River had the highest average contamination, $0.823 \pm 0.03 \mu \mathrm{g} . \mathrm{g}^{-1}$. Considering the possible influence of Garimpo do Lourenço in the contamination levels, samples were taken at 50 and 100 $\mathrm{km}$ from the mining area and at the river mouth. Statistical analyses showed no significant differences between the sampling sites, suggesting that contamination is widespread throughout the course of the river. The Tajaui River is a tributary of the Araguari River, which is one of the main rivers in this region.

Silva-Forsberg et al. (1999) found high levels of mercury in fish and in the hair of the riverine population in the upper part of River Negro Basin, an Amazonian region where gold mining activities are 
rare. Fadinia and Jardim (2001) also found high levels of mercury in rivers, lake waters and in soils in the same region, attributed to the strong soil leaching caused by rains, due to the scarcity of anthropogenic point sources in the region.

The dynamics of mercury in aquatic ecosystems is complex and influenced by many factors, such as soil type, river flow, fish size, season, $\mathrm{pH}$, availability of sites for methylation, among others, which may have influenced the results for the rivers studied here. Although these factors are beyond the scope of this study, they should be considered in future work. According to Moriaty and Walker (1987) and Silva Silva-Forsberg et al. (1999), the high levels of mercury might indicate that mercury is being methylated and bioaccumulated efficiently in the food chain.

Another limitation is the weight and number of samples collected at some sites. In the Jari River, few specimens were collected, while Tajaui was the river with the largest number of samples (70) and highest fish average weight $(2.528 \mathrm{~g})$. As the mercury level is greater in larger fish, it does not rule out a possible trend that needs more detailed studies. In addition, samples were taken in a single season and this can influence the results of mercury concentration found in fish (Uryu et al., 2001).

Furthermore, both anthropogenic and natural sources of mercury are likely to be important to the total mercury levels found (Hacon et al., 2009; Guimarães and Forti, 1999), requiring the use of different methodologies of research (i.e., mercury stable isotopes signatures; Laffont et al., 2011), both in the nearby areas of mining as well as in pristine areas (Laperche et al., 2014).

\section{Conclusion}

This study is the first to assess mercury contamination in the region of the world's largest tropical forest National Park-TNP. The high percentage of $\mathrm{Hg}$ detection in $81 \%$ of the fish examined and the presence of $\mathrm{Hg}$ levels in several fish species higher than those established by the WHO standard guideline, all strongly suggests that mercury is already a significant environmental threat and is a potential health issue across the region.

The average values of mercury concentration in fish in the rivers sampled are similar to those observed in studies conducted in Guianas and Suriname. This suggests that some of the main river basins of Amapá may be impacted by this metal, requiring an extensive sampling in the region. This is important and should be incorporated into environmental frameworks that support decision-making processes at national and regional levels, as well as collaborative projects between the GSE countries.
The most locally consumed carnivorous fish species have high levels of mercury contamination, especially $H$. armatus, $H$. aimara, $S$. rhombeus and $B$. cuvieri. Due to the high consumption of fish by the local population, the reference levels in the literature cannot be applied as safe criteria for consumption of fish contaminated with mercury. This emphasizes the necessity of more detailed studies to identify levels that could be considered safe, considering the target population and data obtained locally or regionally.

Despite the reduction in gold mining activity in the state of Amapá in recent years, a large number of garimpos still persist in the region, mostly illegal, especially those installed within protected areas. Miners continue to use mercury, which is discarded into the environment. Despite being a very important economic activity in many regions of the Amazon, gold mining often results not only in degraded environment but also in poor social conditions, such as widespread diseases among miners (i.e., malaria and sexual transmitted infections). Also, there is increased level of prostitution, violence and slavery in mining areas. In this sense, efforts to reconcile conservation and development must be pursued, reducing misguided trade-offs and overcoming controversial policies.

The results of this study are preliminary, since the proposal was an overview of mercury contamination in priority areas of Amapá, notably within protected areas. High mercury contamination in fish from the main river basins was observed in Amapá, including those areas where no mines are found, indicating that more comprehensive studies should be conducted to identify mercury contamination from sources other than mining. In addition, there is a need to perform monitoring activities in the region and most importantly, contemplate mitigation measures to reduce the effects of current contamination.

\section{Acknowledgment}

This research was commissioned and coordinated by WWF-Brazil/Amazon Program and funded by ECOSIA. Special thanks to Chico Mendes Institute for Biodiversity Conservation for institutional support, Ministry of the Environment/Arpa Program for financial support and Institute of Scientific Research and Technology of the State of Amapá for technical assistance. Special thanks to the managers of Tumucumaque National Park, Amapá National Forest and Cabo Orange National Park, who effectively supported all the fieldwork. We are grateful to Dr. Giorgini Venturieri for statistical analysis, Karen Laurence and Dion I. W. Utreras for their review on the manuscript and we thank the two anonymous reviewers for their constructive comments. 


\section{Author Contributions}

Rossana Venturier: Collected and analyzed the data and wrote the discussion of the manuscript.

Marcelo Oliveira-da-Costa: General coordination, contributed to the ecological aspects of the work, wrote the introduction and conclusions and was responsible for reviewing the manuscript.

Cecile Gama: Collaborated in sample and data collection and helped in species identification.

Christoph Bernhard Jaster: Helped in the interpretation of gold mining sites and discussion.

\section{Conflict of Interest}

The authors declare no ethical issues that may arise after the publication of this manuscript.

\section{References}

Alvarez-Berríos, N.L. and T.M. Aide, 2014. Global demand for gold is another threat for tropical forests. Environ. Res. Lett., 10: 014006-014006. DOI: 10.1088/1748-9326/10/1/014006

Aula, I., H. Braunschweiler, T. Leino, I. Malin and P. Porvari et al., 1994. Levels of mercury in the Tucuruí Reservoir and its surrounding area in Pará, Brazil. Mercury Pollution Integration and Synthesis, pp. 21-40.

Barbosa, A.C., S.R.L. Silva and J.G. Dórea, 1998. Concentration of mercury in hair of indigenous mothers and infants from the Amazon basin. Arch. Environ. Contamin. Toxicol., 34: 100-105. DOI: $10.1007 / \mathrm{s} 002449900291$

Basta, P.C., S.S. Hacon, C.M.V. Ruiz, J.M. Godoy and R.A. Gonaçalves et al., 2016. Avaliação da exposição ambiental ao mercúrio proveniente de atividade garimpeira de ouro na terra indígena Yanomami, Roraima, Amazônia, Brasil.

Bastos, W.R., M.F. Rebelo, M.F. Fonseca, R. Almeida and O. Malm, 2008. A description of mercury in fishes from the Madeira River Basin, Amazon, Brazil. Acta Amazonica, 38: 431-438. DOI: 10.1590/S0044-59672008000300006

Basu, N., A. Scheuhammer, N. Grochowina, K. Klenavic and D. Evans et al., 2005. Effects of mercury on neurochemical receptors in wild river otters (Lontra canadensis). Environ. Sci. Technol., 39: 3585-3591. DOI: $10.1021 / \mathrm{es} 0483746$

Berzas Nevado, J.J., R.C. Rodrigues Martín-Doimeadios, F.J. Guzaman Bernardo, M. Jimenez Moreno and J.L.M. do Nascimento et al., 2010. Mercury in the Tapajós River basin, Brazilian Amazon: A review. Environ. Int., 36: 593-608.

DOI: 10.1016/j.envint.2010.03.011
Bidone, E.D., Z.C. Castilhos, T.M.C. de Souza and L.D. Lacerda, 1997. Fish contamination and human exposure to mercury in the Tapajós River Basin, Pará State, Amazon, Brazil: A screening approach. Bull. Environ. Contamin. Toxicol., 59: 194-201. DOI: 10.1007/s001289900464

Counter, S.A. and L.H. Buchanan, 2004. Mercury exposure in children: A review. Toxicol. Applied Pharmacol., 198: 209-230.

DOI: $10.1016 /$ j.taap.2003.11.032

Crespo-López, M.E., G.L. Macêdo, G.P. Arrifano, N.P. Maria da Conceição and J.L.M. do Nascimento et al., 2011. Genotoxicity of mercury: Contributing for the analysis of Amazonian populations. Environ. Int., 37: 136-141.

DOI: $10.1016 /$ j.envint.2010.08.009

De Oliveira Santos, E.C., I.M. de Jesus, E.S. Brabo, E.C.B. Loureiro and M. da Silvas et al., 2000. Mercury exposures in riverside amazon communities in Pará, Brazil. Environ. Res., 84: 100-107. DOI: 10.1006/enrs.2000.4088

Dolbec, J., D. Mergler, F. Larribe, M. Roulet and J. Lebel et al., 2001. Sequential analysis of hair mercury levels in relation to fish diet of an Amazonian population, Brazil. Sci. Total Environ., 271: 87-97. DOI: $10.1016 / \mathrm{S} 0048-9697(00) 00835-4$

Durrieu, G., R. Maury-Brachet and A. Boudou, 2005. Goldmining and mercury contamination of the piscivorous fish Hoplias aimara in French Guiana (Amazon basin). Ecotoxicol. Environ. Safety, 60: 315-323.

DOI: $10.1016 /$ j.ecoenv.2004.05.004

EPA, 2002. EPA-method 1631, revision e-mercury in water by oxidation, purge and trap and cold vapor atomic fluorescence spectrometry.

Evers, D.C., D.G. Buck and S. Johnson, 2014. Patterns of global seafood mercury concentrations and their relationship with human health and the environment. Biodiversity Research Institute, Portland, Maine, BRI Science Communications Series 2014-29, pp: 16

Fadinia, P.S. and W.F. Jardim, 2001. Is the Negro River Basin (Amazon) impacted by naturally occurring mercury? Sci. Total Environ., 275: 71-82. DOI: 10.1016/S0048-9697(00)00855-X

Guimarães, J. R. D. and M. C. Forti, 1999. Mercury in human and environmental samples from two lakes in Amapá, Brazilian Amazon. Ambio, 28: 296-301.

Gutleb, A. C., C. Schenck and E. Staib, 1997. Giant otter (Pteronura brasiliensis) at risk? Total mercury and methylmercury levels in fish and otter scats, Peru. Ambio, 26: 511-514. 
Gutleb, A.C., A. Kranz, G. Nechay and A. Toman, 1998. Heavy Metal Concentrations in Livers and Kidneys of the Otter (Lutra lutra) from Central Europe. Bull. Environ. Contam. Toxicol., 60: 273-279. DOI: $10.1007 / \mathrm{s} 001289900621$

Hacon, S., P.R.G. Barrocas, A.C.S. de Vasconcellos, C. Barcellos and J.C. Wasserman et al., 2009. Um panorama dos estudos sobre contaminação por mercúrio na Amazônia Legal no período de 1990 a 2005-avanços e lacunas. Geochim. Brasiliensis, 23: $29-48$.

IUCN, 2015. The IUCN Red List of Threatened Species. Version 2015-4.

Kehrig, H.D.A., B.M. Howard and O. Malm, 2008. Methylmercury in a predatory fish (Cichla spp.) inhabiting the Brazilian Amazon. Environ. Pollut., 154: 68-76. DOI: 10.1016/j.envpol.2007.12.038

Kruuk, H. and J.W.H. Conroy, 1991. Mortality of otters (Lutra lutra) in Shetland. J. Applied Ecol., 28: 8394. DOI: $10.2307 / 2404115$

Laffont, L., J.E. Sonke, L. Maurice, S.L. Monrroy and J. Chincheros et al., 2011. Hg speciation and stable isotope signatures in human hair as a tracer for dietary and occupational exposure to mercury. Environ. Sci. Technol., 45: 9910-9916. DOI: $10.1021 / \mathrm{es} 202353 \mathrm{~m}$

Laperche, V., J. Hellal, R. Maury-Brachet, B. Joseph and P. Laporte et al., 2014. Regional distribution of mercury in sediments of the main rivers of French Guiana (Amazonian basin). Springer Plus, 3: 322-322. DOI: 10.1186/2193-1801-3-322

Legg, E.D., P.E. Ouboter and M.A.P. Wright, 2015. SmallScale gold mining related to mercury contamination in the Guianas: A review. WWF Guianas.

Lima, D.P., C. Santos, R.S. Silva, E.T.O. Yoshioka and R.M. Bezerra, 2015. Contaminação por metais pesados em peixes e água da bacia do rio Cassiporé, Estado do Amapá, Brasil. Acta Amazônica, 45: 405-414. DOI: 10.1590/1809-4392201403995

Malm, O., W.C. Pfeiffer, C.M. Souza and R. Reuther, 1990. Mercury pollution due to gold mining in the Madeira River basin, Brazil. Ambio, 19: 11-15.

Martín-Doimeadios, R.R., J.B. Nevado, F.G. Bernardo, M.J. Moreno and G.P.F. Arrifano et al., 2014. Comparative study of mercury speciation in commercial fishes of the Brazilian Amazon. Environ. Sci. Poll. Res., 21: 7466-7479. DOI: $10.1007 / \mathrm{s} 11356-014-2680-7$

Maury-Brachet, R., G. Durrieu, D. Yannick and B. Alain, 2006. Mercury distribution in fish organs and food regimes: Significant relationships from twelve species collected in French Guiana (Amazonian basin). Sci. Total Environ., 368: 262-270.

DOI: $10.1016 /$ j.scitotenv.2005.09.077
Moriaty, F. and C.H. Walker, 1987. Bioaccumulation in food chains-a rational approach. Ecotoxicol. Environ. Safety, 13: 208-2015. DOI: $10.1016 / 0147-6513(87) 90009-1$

Myers, R.H., D.C. Montgomery, G.G. Vinning and T.J. Robinson, 2010. Generalized Linear Models: With Applications in Engineering and the Sciences. 2nd Edn., John Wiley and Sons, Inc, New Jersey, ISBN-10: 0470454636, pp: 496.

Porvari, P., 1995. Mercury levels of fish in Tucuruí hydroelectric reservoir and in River Mojú in Amazonia, in the state of Pará, Brazil. Sci. Total Environ., 175: 109-117. DOI: 10.1016/0048-9697(95)04907-X

Rahm, M., B. Jullian, A. Lauger, R. De Carvalho and L. Vale et al., 2015. Monitoring the impact of gold mining on the forest cover and freshwater in the Guiana shield. REDD+ for the Guiana Shield Project and WWF Guianas.

Santos, C., R.D.S. Silva, E.T.O. Yoshioka and R.M. Bezerra, 2015. Heavy metal contamination in fish and water from Cassiporé River basin, State of Amapá, Brazil. Acta Amazonica, 45: 405-414.

Silva-Forsberg, M.C., B.R. Forsberg and V.K. Zeidemann, 1999. Hg contamination in humans linked to river chemistry in the Amazon basin. Ambio, 28: 519-21

Soares, M.G.M, G. Batista, F.C. Cunha and L. Prestes, 2012. Bioecologia e etnoecologia da ictiofauna na Floresta Nacional do Amapá como subsidio para o manejo de recurso pesqueiro. Conservation International do Brasil, Instituto Chico Mendes, WalmartBrazil.

Sokal, R.R. and F.J. Rohlf, 1995. Biometry: The principles and practice of statistics in biological research Freeman. New York.

Tritsch, I., C. Marmoex, D. Davy, B. Thibaut and V. Gond, 2015. Towards a revival of indigenous mobility in French Guiana? Contemporary transformations of the Wayãpi and Teko territories. Bull. Latin Am. Res., 34: 19-34. DOI: 10.1111/blar.12204

Uryu, Y., O. Malm, I. Thornton, I. Payne and D. Cleary, 2001. Mercury contamination of fish and its implications for other wildlife of the Tapajós Basin, Brazilian Amazon. Conservat. Biol., 15: 438-446. DOI: 10.1046/j.1523-1739.2001.015002438.x

USEPA, 2002. Water quality for the protection of human health: methylmercury. USEPA, Office of Science and Technology, Office of Water, Washington.

Veiga, M.M., G. Angeloci-Santos and J.A. Meech 2014. Review of barriers to reduce mercury use in artisanal gold mining. Extractive Indust. Society, 1: 351-361. DOI: $10.1016 /$ j.exis.2014.03.004 
WHO, 1990. Environmental Health Criteria 101. World Health Organization, Methylmercury. Geneve, Switzerland.

WHO, 2007. Exposure to Mercury: A Major Public Health Concern. World Health Organization, Geneva, Switzerland.

WHO, 2013. Preventing disease through healthy environments. Mercury exposure and health impacts among individuals in the artisanal small-scale gold mining (ASGM) community. World Health Organization, Geneva, Switzerland.
Wren, C.D., 1985. Probable case of mercury poisoning in a wild otter, Lutracanadensis, in northwestern Ontario. Canad. Field-Naturalist, 99: 112-114.

Wren, C.D., 1986. A review of metal accumulation and toxicity in wild mammals: I. Mercury. Environ. Res., 40: 210-244.

DOI: $10.1016 / \mathrm{S} 0013-9351(86) 80098-6$

ZMWG, 2009. Mercury in fish, a global health hazard. Zero Mercury Working Group, Mercury Policy Project. 